\title{
Blik på Balkan
}

\author{
Christian Axboe Nielsen* \\ Institut for Kultur og Samfund, Aarhus Universitet, Danmark
}

Balkan - eller Sydøsteuropa - med deres mange omstridte geografiske betegnelser er og bliver et spændende og aktuelt område. I dag omfatter området både EUmedlemmer og seks lande med forventninger og forhåbninger om at blive medlemmer i de kommende år. Der er sket meget godt siden 1990'erne, hvor Balkan desværre men ikke uden grund - var synonym med krig og "etnisk udrensning". Men Balkan er også fortsat en region, der døjer med mange udfordringer, ikke mindst voksende autokratiske tendenser og "stabilitokratier», der vist nok på sin vis er driftssikre og på overfladen pro-europæiske, men også bugner med klientelisme, korruption og udemokratisk praksis (Nielsen, 2020). Alt for mange dygtige og ambitiøse unge mennesker udvandrer fortsat fra regionen, fordi de ikke har lid til, at deres politikere vil skabe bedre, mere bæredygtige, fredelige og trygge samfund. Den demografiske udsigt er fortsat dyster (BIRN, 2020). Alt for mange politikere i regionen synes, at det er nemmere at nære had og frygt mod nabostater og folk, og alt for mange avisoverskrifter plejer nationalistiske og andre fobiske tendenser for at forhindre, at befolkningen finder på at stille utidige spørgsmål om manglende fremskridt, brudte løfter, korruption og skandaler (Subotić, 2013; Nielsen, 2018). Her skal det dog siges, at de antidemokratiske tendenser ikke udelukkende kan findes på Balkan, men selvfølgelig og beklageligvis også kan konstateres andre steder i Europa og i verden.

Jeg blev i 2019 bedt af dette tidsskrifts redaktion om at være redaktør for et særnummer om Balkan. Jeg begyndte med at danne mig et overblik over forskere i Skandinavien, der på dansk, norsk og svensk beskæftigede sig med Balkan, og besluttede mig hurtigt for at lægge vægt på yngre forskere, der måtte have lyst til at fremvise deres forskning. Det kan siges, at den forskning, der foretages i de nordiske lande angående Balkan, er lige så bred som Balkanforskningen i det hele taget. Forskere har således i de forløbne år publiceret alt fra almene historier om Balkan med noget større fokus på Jugoslavien, velsagtens som resultat af landets turbulente undergang - til artikler om alt fra litteratur, film og musik til migration, freds- og konfliktstudier og selvfølgelig historiske værker og værker om historiebrug. Her byder vi på en samling på tre artikler, der har med vildt forskellige emner at gøre, men der alle på hver sin måde bidrager med spændende ny viden og indblik i regionen.

\footnotetext{
^Kontaktinformasjon: Christian Axboe Nielsen, e-post: christian.a.nielsen@cas.au.dk 
Helga Molbæk-Steensig kaster et skarpt og kritisk blik på menneskerettigheder i Kosovo. Hvem er ansvarlig for at beskytte menneskerettighederne i en meget ny stat, hvor det internationale samfund og dettes organisationer massivt er til stede? Hun spørger blandt andet hvem der skal håndtere krænkelser af menneskerettigheder, hvis disse bliver begået af internationale organisationer, som er til stede $\mathrm{i}$ Kosovo. Det er et ekstremt vigtigt spørgsmål - og desværre ikke kun i Kosovo, da vi i de forløbne år har set FN og andre organisationer blive beskyldt for krænkelser af menneskerettigheder og anden upassende opførsel i for eksempel Haiti og Den Demokratiske Republik Congo.

Langt væk fra både Kosovo og det juridiske finder vi så Fedja Wierød Borčaks spændende litterære analyse. Borčak undersøger både brugen af barnets perspektiv og titoismens arv og rolle i nyere fiktion skrevet af forfattere fra Bosnien og Hercegovina. I sin analyse inddrager Borčak også et betydeligt antal værker fra andre dele af det tidligere Jugoslavien. Borčaks artikel er et ganske udmærket eksempel på nøgtern og nuanceret kritik af nyere litteratur.

Det tredje bidrag stammer fra Sanjin Pejković, der med udgangspunkt i sin ph.d.-afhandling leverer en artikel om den spøjse "mockumentary" ved navnet "Houston, We Have a Problem!" Pejković, der ofte skriver om film og især i sin afhandling beskæftigede sig med dokumentarfilm både i og efter Jugoslavien, fortæller både om selve den kontroversielle film og om den måde, den blev modtaget på.

Alt i alt er der altså tale om tre meget forskellige men også spændende bidrag, der peger i helt forskellige retninger, men også viser, at der i Skandinavien foretages ny og interessant forskning om Balkan. Det skal selvfølgelig siges, at alle tre bidrag har med det tidligere Jugoslavien at gøre, og Balkan er helt sikkert mere end bare det. Jeg vil ønske, at vi også fremover i dette tidsskrift får nogle gode bidrag om de øvrige balkanlande. Jeg håber i hvert fald, at læserne vil nyde disse tre bidrag, og at andre skandinaviske balkanforskere vil lade sig inspirere af bidragene til også selv at levere artikler om Balkan til dette og andre tidsskrifter.

\section{Referencer}

BIRN. (2020). Demographic crisis. Hentet 10. oktober 2020 fra https://balkaninsight.com/reporting-democracy/ demographic-crisis-archive/

Nielsen, C. A. (2018). Collective and competitive victimhood as identity in the former Yugoslavia. I N. Adler (Red.), Understanding the age of transitional justice: Crimes, courts, commissions, and chronicling, (s. 175-193). New Brunswick: Rutgers University Press.

Nielsen, C. A. (2020). Autokratiske tendenser på Balkan. I P. Seeberg \& M. Thorup (Red.), Demokratiets krise og de nye autokratier (s. 153-174). Aarhus: Aarhus Universitetsforlag.

Subotić, J. (2013). Stories states tell: Identity, narrative, and human rights in the Balkans. Slavic Review, 72(2), 306-326. 